Antonio Danesi - Davide Ongari - Cristian Poliziani - Federico Rupi

\title{
EVOLUTION OF THE ROAD AND RAIL TRANSPORT OF GOODS IN EUROPEAN COUNTRIES BEFORE AND AFTER THE FINANCIAL CRISES
}

The main goal of this paper is to analyse recent trends in freight transport volumes as well as their relation to socio-economic and infrastructural variables, in the case of the following major European countries: France, Germany, Italy, Poland, Spain and the United Kingdom. This analysis refers to the period 2005-2016, so that years affected by the global economic crisis, which shows its peak in 2009, are taken into account. This research demonstrated that not all the countries under study show a strong relation between freight traffic and GDP as it could have been expected based on well consolidated experiences and studies. Moreover, other relations are investigated, with mixed results, between the freight traffic volumes and the extension of the rail and road networks as well as oil price data.

Keywords: freight transport, GDP, infrastructures, oil price, road and rail transport networks

\section{Introduction}

Traditionally, the freight transport volumes are considered to depend on several socio-economic variables, as well as variables directly related to the transport system, such as the extension and features of transport network and oil price [1-2]. The main socio-economic variable, whose impact is typically considered to be the most relevant one on the freight traffic volumes, is the Gross Domestic Product (GDP) [3-7]; theoretically, more goods are produced and more will have to be transported within the country under consideration. Moschovou [8] illustrated this relation focusing on the recent period of crisis in Greece. Moreover, kilometres of the road and rail infrastructures in the country can affect the total freight transport [9-13]. In addition, oil price affects freight transport [14-15]: across the board, the higher the oil price is, the higher will be the amount of goods that will be transported by train rather than truck. In this paper, the above mentioned relations and factors are analysed under qualitative as well as quantitative perspectives, for six among the major European countries and with reference to the period 2005-2016.

\section{The data set}

Both socio-economic and transport system variables are taken into account, in the case of six European countries, with similar territorial surface and population, i.e. France, Germany, Italy, Poland, Spain and the United Kingdom.

All these countries are populated by between 40 and 80 million of inhabitants and show a surface of between
250 and 650 thousands square kilometers. For each country, data about the GDP, transport supply and freight transport volumes between year 2005 and 2016 are taken into consideration from different data sources [16-18], in order to investigate their statistical relations.

\subsection{The Gross Domestic Product}

Figure 1 shows the trends in the GDP values, collected from the Eurostat database for each European country belonging to the study sample, with reference to the period 2005-2016. All the GDP data are expressed in billion of euros, with reference to chain-linked values, taking 2010 as the base year. The economic crisis has shown its peak point after 2008, causing a turnaround in GDP trends for all the countries analysed, with the only exception of Poland. The UK, but especially Italy, show a significant decline: however, while the UK after 2008 has shown a strong recovery, the recovery for Italy has not been completed yet and Italian GDP in 2016 is the only one, which is still lower than that of 2005 .

From 2005 to 2016, Poland shows a total growth in its GDP of $50.8 \%$, proving to be much more dynamic compared to the other countries, that register a total growth between $8 \%$ and $18 \%$ only, for the whole period: $10 \%$ for France, $18 \%$ for Germany, $8 \%$ for Spain and $16 \%$ for the UK. Only Italy shows a negative growth rate equal to $-3 \%$. Poland seems not to have perceived the economic crisis at all, showing a constant growth along the study period.

\footnotetext{
Antonio Danesi ${ }^{1}$, Davide Ongari ${ }^{2}$, Cristian Poliziani ${ }^{1, *}$, Federico Rupi ${ }^{1}$

${ }^{1}$ Department of Civil, Chemical, Economic and Environmental Engineering, University of Bologna, Italy

${ }^{2}$ Freelance transport analyst, Milan, Italy

*E-mail of corresponding author: cristian.poliziani2@unibo.it
} 


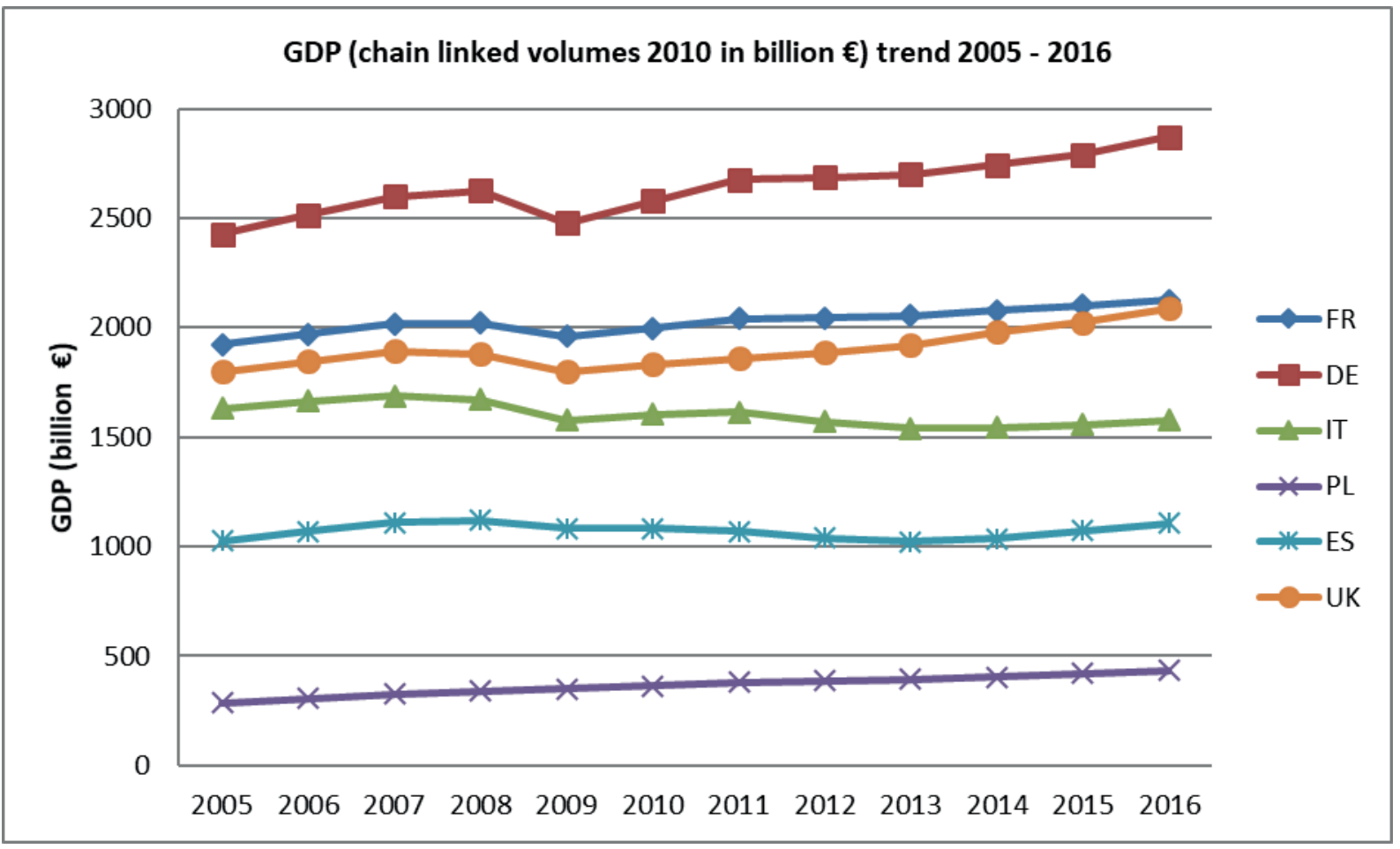

Figure 1 2005-2016 GDP trends, in billions of euros, calculated in chain linked values (base year: 2010), for the countries under study

Table 1 Railway total length (km)

\begin{tabular}{ccccccccccccccc}
\hline Country & 2005 & 2006 & 2007 & 2008 & 2009 & 2010 & 2011 & 2012 & 2013 & 2014 & 2015 & 2016 & $\Delta \%$ & $\Delta$ \\
\hline FR & 29286 & 29463 & 29918 & 29901 & 29903 & 29871 & 30404 & 30581 & 29784 & 30905 & 28808 & 28364 & -3.2 & -922 \\
DE & 34221 & 34122 & 33890 & 33855 & 33714 & 33707 & 33576 & 33509 & 38703 & 38836 & 38828 & 38990 & 14.0 & 4769 \\
IT & 16545 & 16627 & 16667 & 16861 & 17004 & 17022 & 17045 & 17060 & 17070 & 17037 & 17041 & 17096 & 3.3 & 551 \\
PL & 19507 & 19429 & 19419 & 19627 & 19764 & 19702 & 19725 & 19617 & 18959 & 18942 & 18510 & 18429 & -5.5 & -1078 \\
ES & 15015 & 15212 & 15554 & 15550 & 15330 & 15837 & 15932 & 15922 & 15937 & 15901 & 16050 & 15922 & 6.0 & 907 \\
UK & 16208 & 16193 & 16212 & 16212 & 16151 & 16175 & 16408 & 16423 & 16423 & 16209 & 16209 & 16253 & 0.3 & 45 \\
\hline
\end{tabular}

Table 2 Motorway total length ( $\mathrm{km}$ )

\begin{tabular}{ccccccccccccccc}
\hline Country & 2005 & 2006 & 2007 & 2008 & 2009 & 2010 & 2011 & 2012 & 2013 & 2014 & 2015 & 2016 & $\Delta \%$ & $\Delta$ \\
\hline FR & 10798 & 10848 & 10958 & 11042 & 11163 & 11392 & 11413 & 11413 & 11552 & 11560 & 11599 & 11612 & 7.5 & 814 \\
DE & 12363 & 12531 & 12594 & 12645 & 12813 & 12819 & 12845 & 12879 & 12917 & 12949 & 12993 & 12996 & 5.1 & 633 \\
IT & 6542 & 6554 & 6588 & 6629 & 6661 & 6668 & 6668 & 6726 & 6751 & 6844 & 6943 & 6943 & 6.1 & 401 \\
PL & 552 & 583 & 663 & 765 & 849 & 857 & 1070 & 1365 & 1482 & 1556 & 1559 & 1640 & 197.1 & 1088 \\
ES & 11432 & 12073 & 13013 & 13518 & 14021 & 14262 & 14554 & 14701 & 14981 & 15049 & 15336 & 15444 & 35.1 & 4012 \\
UK & 3665 & 3669 & 3673 & 3674 & 3672 & 3686 & 3733 & 3756 & 3760 & 3769 & 3768 & 3764 & 2.7 & 99 \\
\hline
\end{tabular}

\subsection{Extension of road and rail networks}

Table 1 and Table 2 show the level of transport supply for rail and road transport systems, in terms of corresponding network extension. Table 1 shows, for each country, the total length of railways, the corresponding percentage growth in the study period $(\Delta \%)$ and the absolute variations $(\Delta)$ in terms of kilometers added to the total infrastructure length. The most relevant growth in terms of extension of rail infrastructure has occurred in Germany, where the network has increased by more than $4,700 \mathrm{~km}(+14 \%)$. On the other hand, in Poland, the rail network has decreased by approximatively $1,000 \mathrm{~km}$ $(-5.5 \%)$.

Table 2 shows the total length of motorways, the corresponding percentage growth in the study period $(\Delta \%)$ and the absolute variations in terms of kilometers added to the road infrastructure $(\Delta)$ : in the latter case, for all of the countries under study, an increase in network length has been registered, with particular regard to the 
Table 3 Crude Oil, Europe Spot Price FOB (dollars per barrel)

\begin{tabular}{cccccccccccccc}
\hline 2005 & 2006 & 2007 & 2008 & 2009 & 2010 & 2011 & 2012 & 2013 & 2014 & 2015 & 2016 & $\Delta \%$ \\
\hline 54.58 & 65.17 & 72.51 & 96.94 & 61.74 & 79.61 & 111.38 & 110.80 & 108.56 & 96.97 & 52.30 & 43.64 & -20.0 \\
\hline
\end{tabular}

Table 4 National and international road and rail freight volumes (billion ton-km)

\begin{tabular}{ccccccccccccccc}
\hline Country & 2005 & 2006 & 2007 & 2008 & 2009 & 2010 & 2011 & 2012 & 2013 & 2014 & 2015 & 2016 & $\Delta \%$ \\
\hline FR & 246.0 & 252.6 & 261.8 & 246.7 & 205.7 & 212.2 & 219.9 & 204.9 & 203.7 & 197.8 & 187.9 & 188.4 & $-23.4 \%$ \\
DE & 405.5 & 437.0 & 458.0 & 457.2 & 403.3 & 420.4 & 437.1 & 417.1 & 418.3 & 422.7 & 428.7 & 431.4 & $+6.4 \%$ \\
IT & 234.6 & 211.3 & 204.7 & 204.3 & 185.4 & 194.4 & 162.6 & 144.2 & 146.2 & 138.0 & 137.6 & 135.3 & $-42.3 \%$ \\
PL & 161.8 & 181.9 & 205.2 & 216.9 & 224.2 & 251.0 & 261.5 & 271.2 & 298.5 & 301.0 & 311.3 & 341.4 & $+111.0 \%$ \\
ES & 244.8 & 253.3 & 270.1 & 254.0 & 2197 & 219.0 & 216.3 & 208.7 & 201.9 & 206.2 & 220.5 & 227.5 & $-7.1 \%$ \\
UK & 182.7 & 1874 & 192.3 & 181.4 & 158.7 & 165.3 & 174.5 & 179.9 & 169.6 & 165.3 & 180.9 & 172.1 & $-5.8 \%$ \\
\hline
\end{tabular}

Table 5 National and international rail freight volumes (billion ton- $\mathrm{km}$ )

\begin{tabular}{cccccccccccccccccc}
\hline Country & 2005 & 2006 & 2007 & 2008 & 2009 & 2010 & 2011 & 2012 & 2013 & 2014 & 2015 & 2016 & $\Delta \%$ \\
\hline FR & 40.7 & 41.2 & 42.6 & 40.4 & 32.1 & 30.0 & 34.2 & 32.5 & 32.2 & 32.6 & 34.3 & 32.6 & -19.9 \\
DE & 95.4 & 107.0 & 114.6 & 115.7 & 95.8 & 107.3 & 113.3 & 110.1 & 112.6 & 112.6 & 114.0 & 116.2 & +21.8 \\
IT & 22.8 & 24.2 & 25.3 & 23.8 & 17.8 & 18.6 & 19.8 & 20.2 & 19.0 & 20.2 & 20.8 & 22.7 & -0.3 \\
PL & 50.0 & 53.6 & 54.3 & 52.0 & 43.5 & 48.7 & 53.8 & 48.9 & 50.9 & 50.1 & 50.6 & 50.7 & +1.5 \\
ES & 11.6 & 11.5 & 11.2 & 11.0 & 7.8 & 8.9 & 9.5 & 9.5 & 9.3 & 10.4 & 11.1 & 10.5 & -9.4 \\
UK & 21.5 & 21.9 & 21.3 & 21.0 & 19.2 & 18.6 & 21.0 & 21.4 & 22.4 & 22.1 & 22.0 & 17.1 & -20.2 \\
\hline
\end{tabular}

case of Poland and Spain. Poland, in particular, shows a triplication in its total motorway length during the period under consideration. In absolute terms, the most relevant growth in the extension of motorway network has occurred in Spain, with an increase of more than 4,000 km from 2005 to 2016 .

\subsection{The oil price}

In Table 3, oil price trend calculated in dollars per barrel of crude oil is reported, with reference to the period 2005-2016. Significant changes in oil prices have occurred in the period under study, with a decrease by $20 \%$. Price of crude oil can be considered as a proxy of pump price values, which can vary very much between different pump stations and countries [19].

\subsection{National and international freight transport by road and rail}

This paragraph deals with the analysis of the national and international haulage, both by rail and road, from 2005 to 2016 .

Table 4 shows the total national and international freight transport reported by carriers registered in the countries under analysis, with reference to both road and rail operations. The highest total traffic increase has been registered by Poland $(+111.0 \%)$, while Italy has recorded the worst performance, with a decrease of total freight transport by $42.3 \%$.

In the case of the rail freight (Table 5), data sets are based on the Regulation (EC) 91/2003 of the European Parliament and Council (2002) on rail transport statistics. Rail freight transport statistics show that, from 2008 to 2009 , the decrease in transported goods is very significant. In 2009 the overall decrease in the goods transported by rail is equal to $18.1 \%$ with reference to the study sample. On the other hand, the total variation in rail freight transport from 2005 to 2016 is equal to $+3.2 \%$, i.e. equivalent to 7.9 billion ton-km, as far as the whole countries included in the study sample are concerned. Statistics about road haulage are presented in Table 6, based on the Council Regulation (EC) $1172 / 1998$, so that reporting countries may exclude vehicles for road transport, whose load capacity is lower than 3.5 ton or maximum permissible laden weight is lower than 6 ton.

Table 6 shows the national and international road haulage expressed in billion ton-km, by vehicles registered in the reporting country, including cross-trade and cabotage. From 2008 to 2009, only Poland shows some traffic increases. All other countries seem to be affected by the global economic crisis, subsequently overcome by all countries, with the only exception of Italy, which shows a further significant reduction in road haulage between 2010 and $2016(-6 \%)$. The total variation in road haulage, as far as all countries included in the study sample are concerned, is equal to $+1.0 \%$, i.e. equivalent to 12.8 billion ton-km.

By comparing data reported in Tables 4-6, different trends emerge for the countries under study: France, Spain 
Table 6 National and international road freight volumes (billion ton-km)

\begin{tabular}{cccccccccccccc}
\hline Country & 2005 & 2006 & 2007 & 2008 & 2009 & 2010 & 2011 & 2012 & 2013 & 2014 & 2015 & 2016 & $\Delta \%$ \\
\hline FR & 205.3 & 211.4 & 219.2 & 206.3 & 173.6 & 182.2 & 185.7 & 172.4 & 171.5 & 165.2 & 153.6 & 155.8 & -24.1 \\
DE & 310.1 & 330 & 343.4 & 341.5 & 307.5 & 313.1 & 323.8 & 307 & 305.7 & 310.1 & 314.7 & 315.2 & +1.6 \\
IT & 211.8 & 187.1 & 179.4 & 180.5 & 167.6 & 175.8 & 142.8 & 124 & 127.2 & 117.8 & 116.8 & 112.6 & -46.8 \\
PL & 111.8 & 128.3 & 150.9 & 164.9 & 180.7 & 202.3 & 207.7 & 222.3 & 247.6 & 250.9 & 260.7 & 290.7 & +160.0 \\
ES & 233.2 & 241.8 & 258.9 & 243 & 211.9 & 210.1 & 206.8 & 199.2 & 192.6 & 195.8 & 209.4 & 217 & -7.0 \\
UK & 161.3 & 165.5 & 171 & 160.3 & 139.5 & 146.7 & 153.5 & 158.5 & 147.2 & 143.2 & 158.9 & 155 & -3.9 \\
\hline
\end{tabular}

Table 7 National road haulage (billion ton- $\mathrm{km}$ )

\begin{tabular}{cccccccccccccc}
\hline Country & 2005 & 2006 & 2007 & 2008 & 2009 & 2010 & 2011 & 2012 & 2013 & 2014 & 2015 & 2016 & $\Delta \%$ \\
\hline FR & 177.3 & 182.8 & 191.4 & 181.9 & 156.0 & 164.3 & 168.2 & 156.4 & 155.7 & 151.1 & 141.2 & 144.2 & -18.7 \\
DE & 237.6 & 251.4 & 261.4 & 264.5 & 245.6 & 252.5 & 265.0 & 254.5 & 256.7 & 263.0 & 269.7 & 271.7 & +14.3 \\
IT & 171.6 & 155.4 & 152.4 & 151.8 & 145.6 & 149.2 & 127.7 & 111.8 & 112.0 & 102.4 & 104.1 & 100.3 & -41.6 \\
PL & 60.9 & 59.4 & 65.8 & 71.9 & 79.2 & 82.2 & 89.7 & 89.0 & 100.3 & 96.6 & 104.7 & 106.6 & +75.0 \\
ES & 166.4 & 174.6 & 190.6 & 175.2 & 151.1 & 146.2 & 142.3 & 133.4 & 127.0 & 128.2 & 137.2 & 145.0 & -12.9 \\
UK & 151.2 & 154.8 & 160.7 & 151.1 & 131.6 & 137.8 & 139.9 & 142.6 & 131.3 & 127.7 & 142.9 & 148.7 & -1.7 \\
\hline
\end{tabular}

Table 8 Road transport performance adjusted for territoriality (billion ton-km)

\begin{tabular}{cccccccccccccc}
\hline Country & 2005 & 2006 & 2007 & 2008 & 2009 & 2010 & 2011 & 2012 & 2013 & 2014 & 2015 & 2016 & $\Delta \%$ \\
\hline FR & 294.5 & 303.9 & 315.3 & 301.4 & 261.7 & 275.1 & 273.4 & 259.1 & 263.7 & 259.8 & 249.4 & 258.1 & -12.4 \\
DE & 370.8 & 394.5 & 413.2 & 420.0 & 385.3 & 404.9 & 417.6 & 408.2 & 416.7 & 426.9 & 427.5 & 447.7 & +20.7 \\
IT & 204.0 & 190.1 & 186.8 & 187.5 & 176.4 & 183.6 & 157.3 & 139.5 & 141.8 & 133.0 & 133.5 & 132.0 & -35.3 \\
PL & 86.8 & 91.0 & 95.3 & 101.6 & 107.4 & 116.2 & 125.6 & 127.9 & 141.5 & 138.5 & 147.3 & 154.2 & +77.7 \\
ES & 210.7 & 220.1 & 237.3 & 217.3 & 189.4 & 184.4 & 179.9 & 169.8 & 166.1 & 167.1 & 177.9 & 186.7 & -11.4 \\
UK & 167.3 & 171.5 & 178.1 & 167.7 & 145.0 & 151.5 & 157.6 & 163.4 & 152.2 & 149.6 & 165.9 & 185.6 & +10.9 \\
\hline
\end{tabular}

and the United Kingdom show a decrease both in the road and rail freight volumes, between 2005 and 2016. In the same period, Italian carriers show a strong contraction of road freight, while rail haulage is almost constant. On the other hand, Germany shows a relevant growth in both road and rail transport and Poland shows a very high increase in road haulage, while rail haulage has registered only a very limited growth between 2005 and 2016. Table 7 reports data regarding national road freight transport by carriers registered in the corresponding country, while Table 8 reports data regarding national road freight transport adjusted for territoriality. The latter values account for haulage performed within the territory of each country by any vehicles, without considering the cross-trade and cabotage. The total variation of national haulage, by considering all the countries included in the study sample, is equal to $-5.1 \%$, i.e. equivalent to 7.9 billions of ton-km, for national road haulage, between 2005 and 2016. As far as the adjustment for territoriality is taken into consideration, an increase by $+2.2 \%$, i.e. equivalent to 30.2 billion of ton- $\mathrm{km}$, for the national road transport performance has been registered. The latter observation seems to indicate that road transport market of the countries under study has seen a significant shift of freight traffic from local operators to operators registered in other countries.
Table 9 shows the signs of the total percentage variation of freight transport volumes in each country under study, for what concerns both rail and road haulage, between 2005 and 2016. Each country shows the same sign for the variation in rail and road haulage, as well as for total and national adjusted data, with the only exception of the United Kingdom. Indeed, the United Kingdom shows an increase only in the national adjusted road freight, while all other values show a negative sign. This is related to the fact that, in these years, carriers from different European countries have started working in the UK, replacing some local operators, probably to minimize service costs. Table 10 shows the adjusted road freight transport share controlled by carriers registered in the corresponding country (national road freight divided by the adjusted road freight). Only the United Kingdom, Italy and France show a high decrease in this value, due to the high increase in the adjusted road freight compared to the national one. In particular, the decreasing of this value for the United Kingdom is a consequence of the phenomenon highlighted in Table 9. France and Germany are the countries having recorded the highest percentage of freight traffic by foreign companies, in absolute terms. 
Table 9 Sign of total percentage variation of rail and road freight between 2005 and 2016

\begin{tabular}{ccccc}
\hline Country & Rail freight & Nat. and int. road freight & Nat. road freight & Nat. adjusted road freight \\
\hline FR & - & - & + & - \\
DE & + & - & + \\
IT & - & + & - \\
PL & + & - & - \\
ES & - & - & + \\
UK & - & & + \\
\hline
\end{tabular}

Table 10 National share of total freight transport - changes between 2005 and 2016

\begin{tabular}{cccc}
\hline Country & 2005 & 2016 & $\Delta$ \\
\hline FR & $60.2 \%$ & $55.9 \%$ & $-7.2 \%$ \\
DE & $64.1 \%$ & $60.7 \%$ & $-5.3 \%$ \\
IT & $84.1 \%$ & $76.0 \%$ & $-9.7 \%$ \\
PL & $70.2 \%$ & $69.1 \%$ & $-1.5 \%$ \\
ES & $79.0 \%$ & $77.7 \%$ & $-1.7 \%$ \\
UK & $90.4 \%$ & $80.1 \%$ & $-11.3 \%$ \\
\hline
\end{tabular}

Table 11 Elasticity and $R$-square values for relationships between the rail and road freight traffic from 2005 to 2016 and socio-economic and transport system variables (n.s. and f. are abbreviations for "not statistically significant" and "freight")

\begin{tabular}{|c|c|c|c|c|c|c|c|c|c|c|}
\hline \multirow{2}{*}{$\begin{array}{l}\text { E - R-square } \\
\text { GDP - Road f. }\end{array}$} & \multicolumn{2}{|c|}{ FR } & \multicolumn{2}{|c|}{$\mathrm{DE}$} & \multicolumn{2}{|c|}{ IT } & \multicolumn{2}{|c|}{ PL } & \multirow{2}{*}{$\begin{array}{l}\text { ES } \\
\text { n.s. }\end{array}$} & \multirow{2}{*}{$\frac{\text { UK }}{\text { n.s. }}$} \\
\hline & & & 0.71 & 0.79 & 4.90 & 0.64 & 1.58 & 0.96 & & \\
\hline GDP - Rail f. & & & 1.08 & 0.66 & 2.60 & 0.53 & \multicolumn{2}{|c|}{ n.s. } & n.s. & n.s. \\
\hline Motorway - Road f. & & & \multicolumn{2}{|c|}{ n.s. } & \multicolumn{2}{|c|}{ n.s. } & 0.49 & 0.95 & n.s. & n.s. \\
\hline Railway - Rail f. & \multicolumn{2}{|c|}{ n.s. } & \multicolumn{2}{|c|}{ n.s. } & \multicolumn{2}{|c|}{ n.s. } & \multicolumn{2}{|c|}{ n.s. } & n.s. & n.s. \\
\hline Motorway - Rail f. & -3.73 & 0.69 & \multicolumn{2}{|c|}{ n.s. } & \multicolumn{2}{|c|}{ n.s. } & \multicolumn{2}{|c|}{ n.s. } & n.s. & n.s. \\
\hline Oil price - Road f. & \multicolumn{2}{|c|}{ n.s. } & \multicolumn{2}{|c|}{ n.s. } & \multicolumn{2}{|c|}{ n.s. } & \multicolumn{2}{|c|}{ n.s. } & n.s. & n.s. \\
\hline Oil price - Rail f. & \multicolumn{2}{|c|}{ n.s. } & \multicolumn{2}{|c|}{ n.s. } & \multicolumn{2}{|c|}{ n.s. } & \multicolumn{2}{|c|}{ n.s. } & n.s. & n.s. \\
\hline
\end{tabular}

\section{Regression analysis}

In this paragraph, relations between freight transport data and the values associated to the other independent variables, which are related both to the socio-economic sector, as well as the transport supply sub-system, are evaluated in terms of both linear and logarithmic regression analysis. In this framework, the elasticity of freight traffic, with respect to the independent variables, is estimated for all the countries included in the sample under study. Figure 2 shows for each country the comparison between the absolute values of national road haulage, national and international rail haulage and GDP, in the period 2005-2016. For Germany, Poland and Spain the freight transport trends appear to be strongly related to the GDP trends registered in the corresponding countries-Figure 3 shows the annual variations of the national and international rail and road haulage. Again, trends in the GDP are included in this charts and in the case of France, Germany and Poland, they seem to reproduce freight transport annual rates of increase well.

This analysis confirms that the economic crisis and the consequent austerity applied by the governments, which started in 2008, had the effect of producing a drastic decrease in terms of transported goods, both by road and rail. The rail freight traffic reduction was particularly strong. The country that lost the smallest amount of traffic is Poland, whose economy is growing in a fast way, like other East-European countries. The main results of the elasticity analysis performed in this research between the analysed variables are presented in Table 11 .

More in detail, Table 11 reports the R-square and elasticity values for different pairs of attributes and for each country, with reference to the period 2005-2016. Statistical results leading either to the low $\mathrm{R}$-square values or to counterintuitive signs of coefficients are omitted in Table 11. The existence of a link between GDP trends and road and rail haulage seems to be valid, at least for some countries of the sample under study, with special regard to Germany and Italy. High values of elasticity for Italy, compared to the expected ones based on the scientific literature, are possibly due to the huge loss in terms of freight transport in a period of the GDP stagnation. Relations between the freight traffic and infrastructural variables are not statistically significant, with the only 

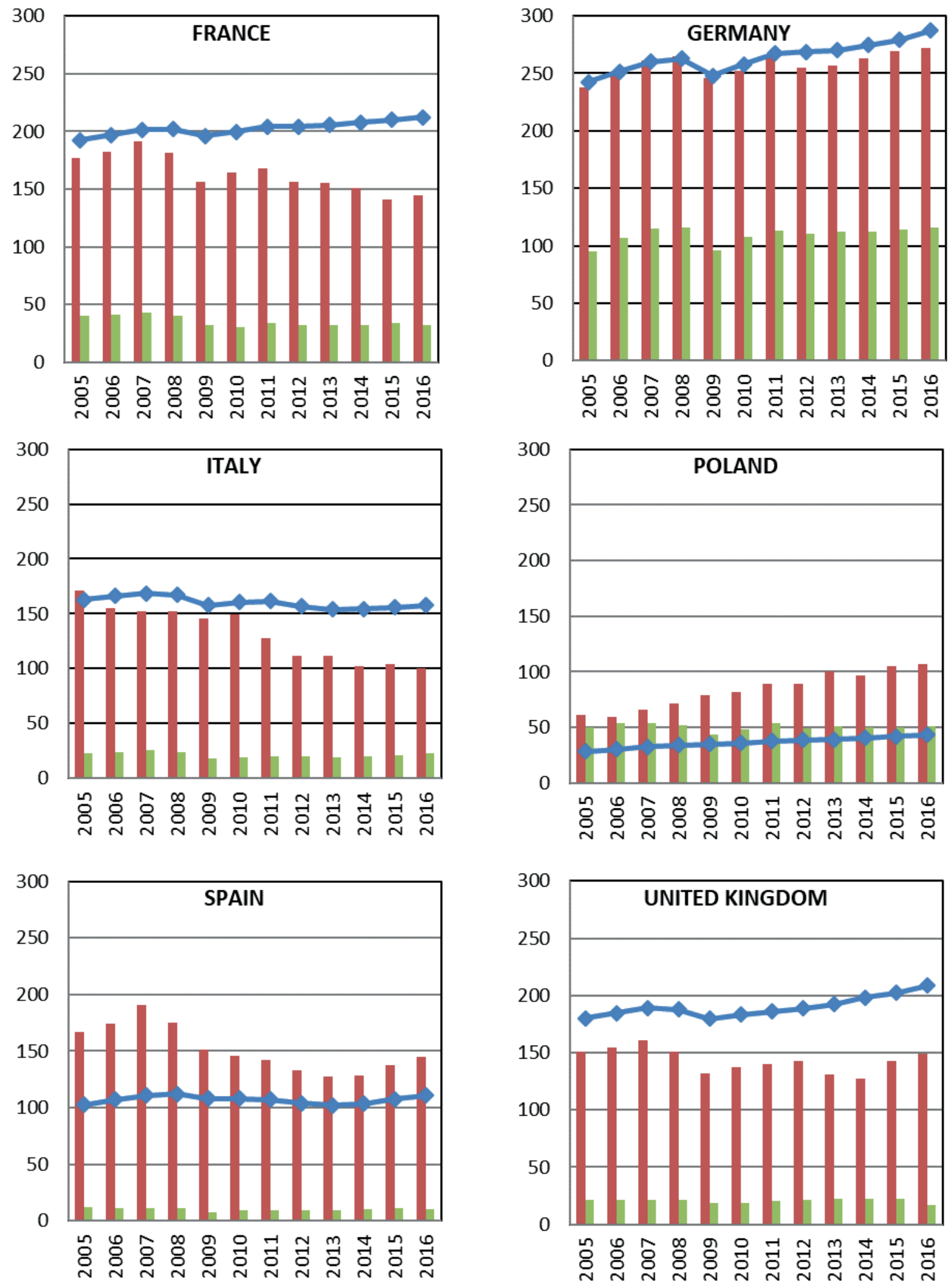

Nat. road freight, billion $\mathrm{t}-\mathrm{km} \quad$ Nat. And inter. rail freight, billion $\mathrm{t}-\mathrm{km} \multimap \mathrm{GDP}$, tens of billion $€$

Figure 2 Absolute values of national road haulage, national and international rail haulage and GDP, between 2005 and 2016

exception of Poland, which has experienced a relevant variation on both the motorway length and the road freight, so that an elasticity of 0.49 with an R-square of 0.95 has been calculated. The cross-elasticity analysis between motorway length and rail freight has been performed: only the case of France confirms the statistical significance of this relation. All the statistically significant relations satisfy 
FRANCE

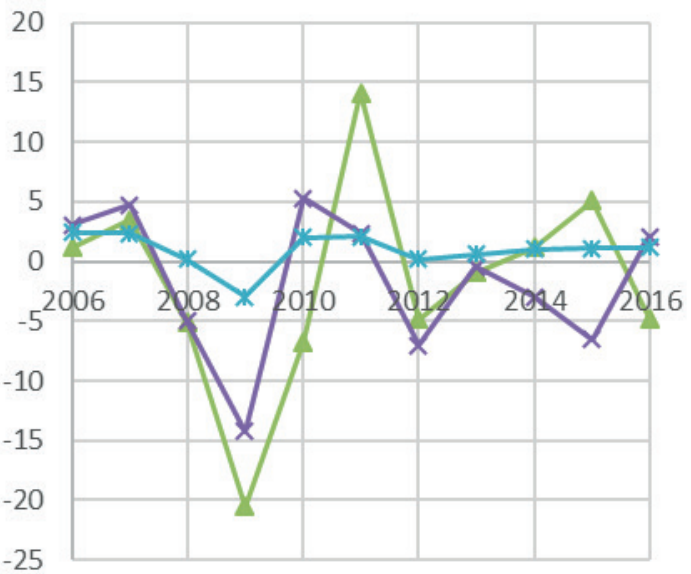

ITALY

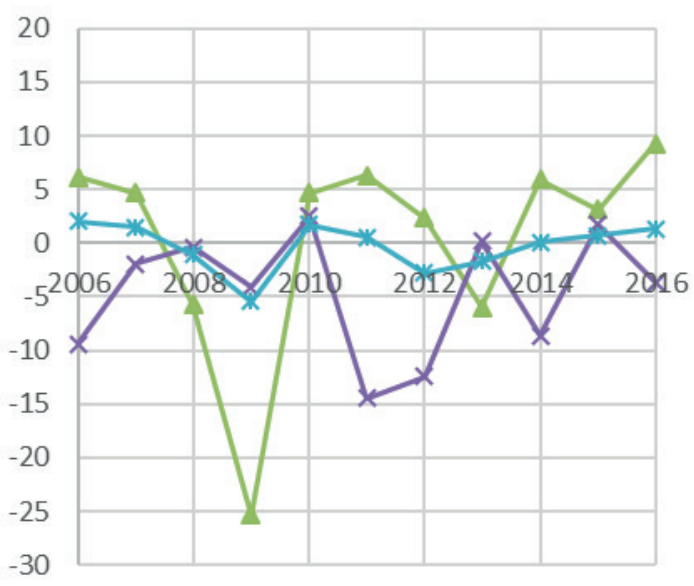

SPAIN

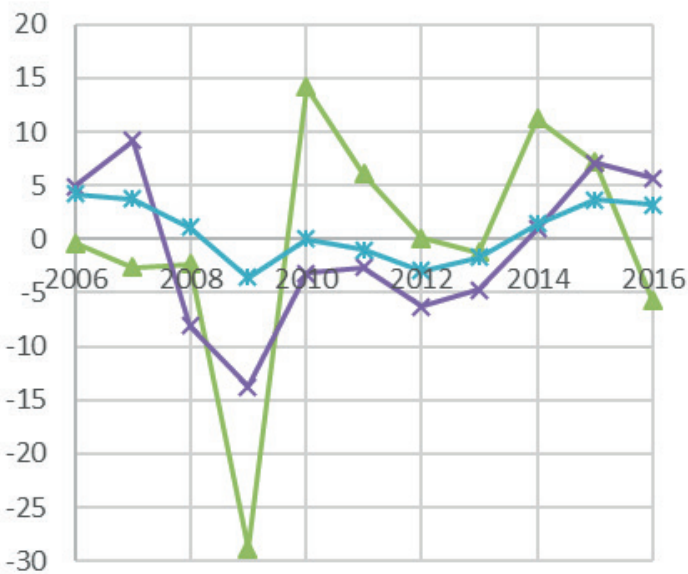

Nat. and int. Rail freight
GERMANY

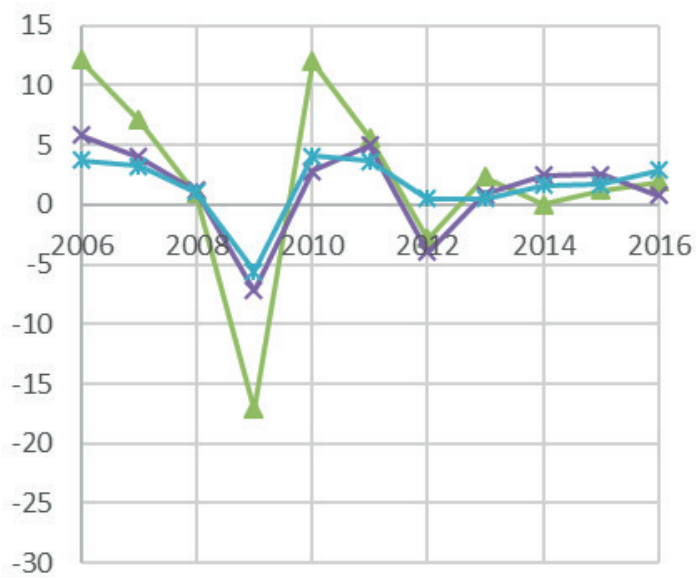

POLAND

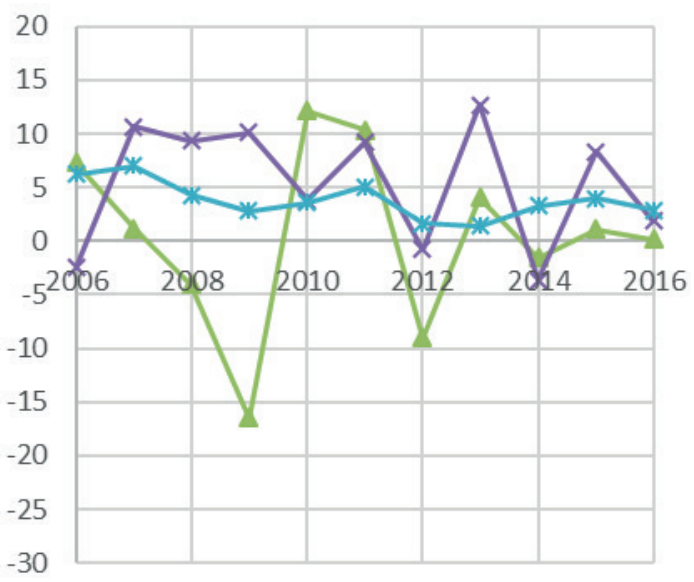

UNITED KINGDOM

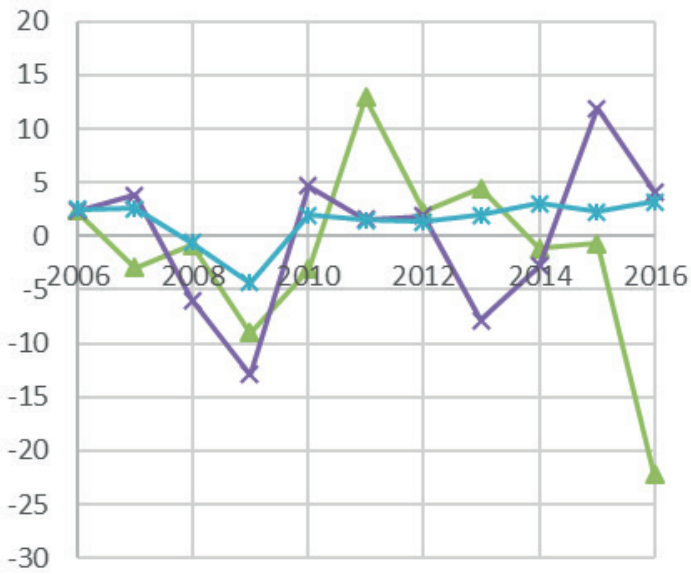

Nat. Road freight $\longrightarrow$ GDP

Figure 3 Annual rate of increase of GDP, national road freight and national and international rail freight between 2005 and 2016

the t-student test for their coefficient, showing t-values that range between 3 and 7 .
A further relation has been analysed by taking into account the rail share of the freight transport in the European Union (Table 12) and the oil price registered 
Table 12 European share of rail freight for the European Union - changes between the 2005 and 2016

\begin{tabular}{ccccccccccccc}
\hline 2005 & 2006 & 2007 & 2008 & 2009 & 2010 & 2011 & 2012 & 2013 & 2014 & 2015 & 2016 & $\Delta \%$ \\
\hline $11.50 \%$ & $11.80 \%$ & $12.00 \%$ & $12.00 \%$ & $11.00 \%$ & $11.40 \%$ & $12.10 \%$ & $12.00 \%$ & $11.90 \%$ & $11.80 \%$ & $11.90 \%$ & $11.20 \%$ & $-2.6 \%$ \\
\hline
\end{tabular}

Italy

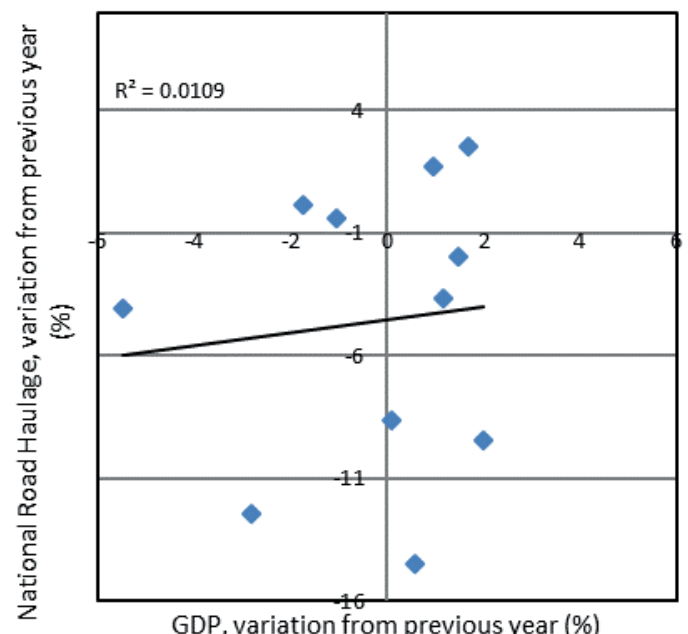

Germany

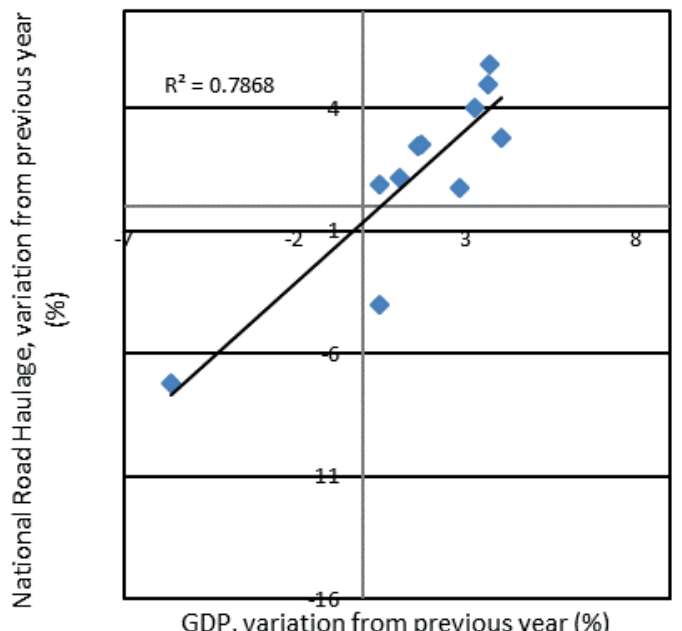

GDP, variation from previous year (\%)

Figure 4 Relation between the annual rate of increase of GDP and national road haulage, for Italy and Germany

Poland

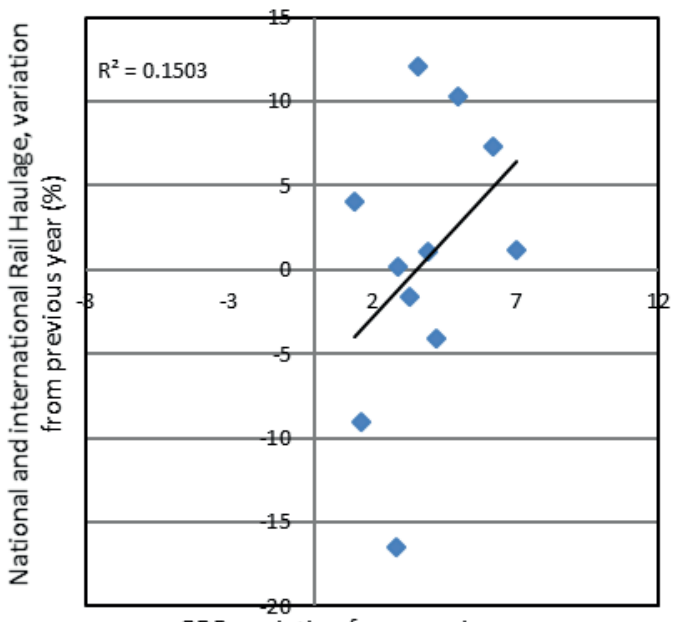

GDP, variation from previous year
Germany

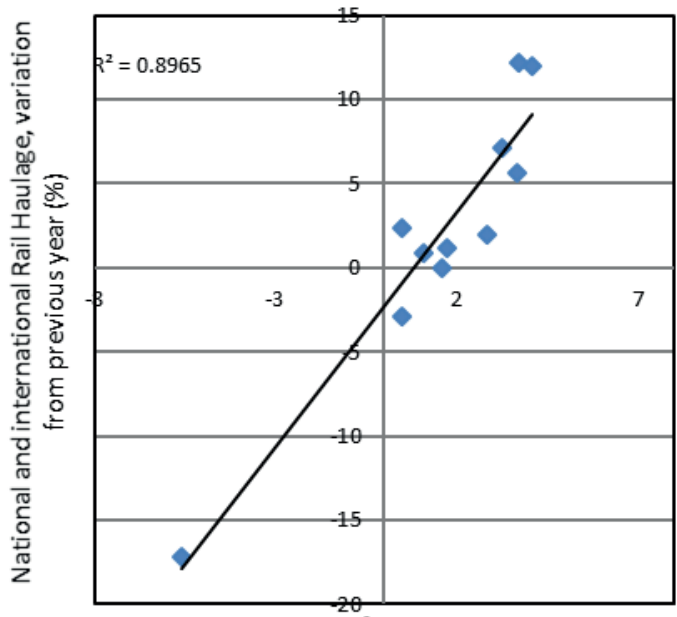

GDP, variation from previous year

Figure 5 Relation between the annual rate of increase of GDP and national and intermational rail haulage, for Poland and Germany

in the same year. The relation between the percentage variation of these two variables has resulted to be quite low with an R-square equal to 0.48 ; moreover, by excluding values related to the exceptional cases of years 2008 and 2015 (outliers), the R-square regression value becomes equal to 0.94. As a consequence, increases in oil price seem to contribute effectively to the increase in the modal share controlled by the rail operations, compared to road operations, thus resulting in a significant decrease in $\mathrm{CO}_{2}$ emissions, to a different extent in different countries.
Finally, Figures 4 and 5 present the results of the linear regressions estimated between the GDP annual rate of increase and annual rate of increase in national road freight as well as national and international rail freight traffic volumes. It can be noted that Germany shows a strong relationship between these variables, while for Italy and Poland no statistically significant relationship has been observed.

Moreover, Figure 6 presents the correlation existing between the railway length and rail haulage registered in 


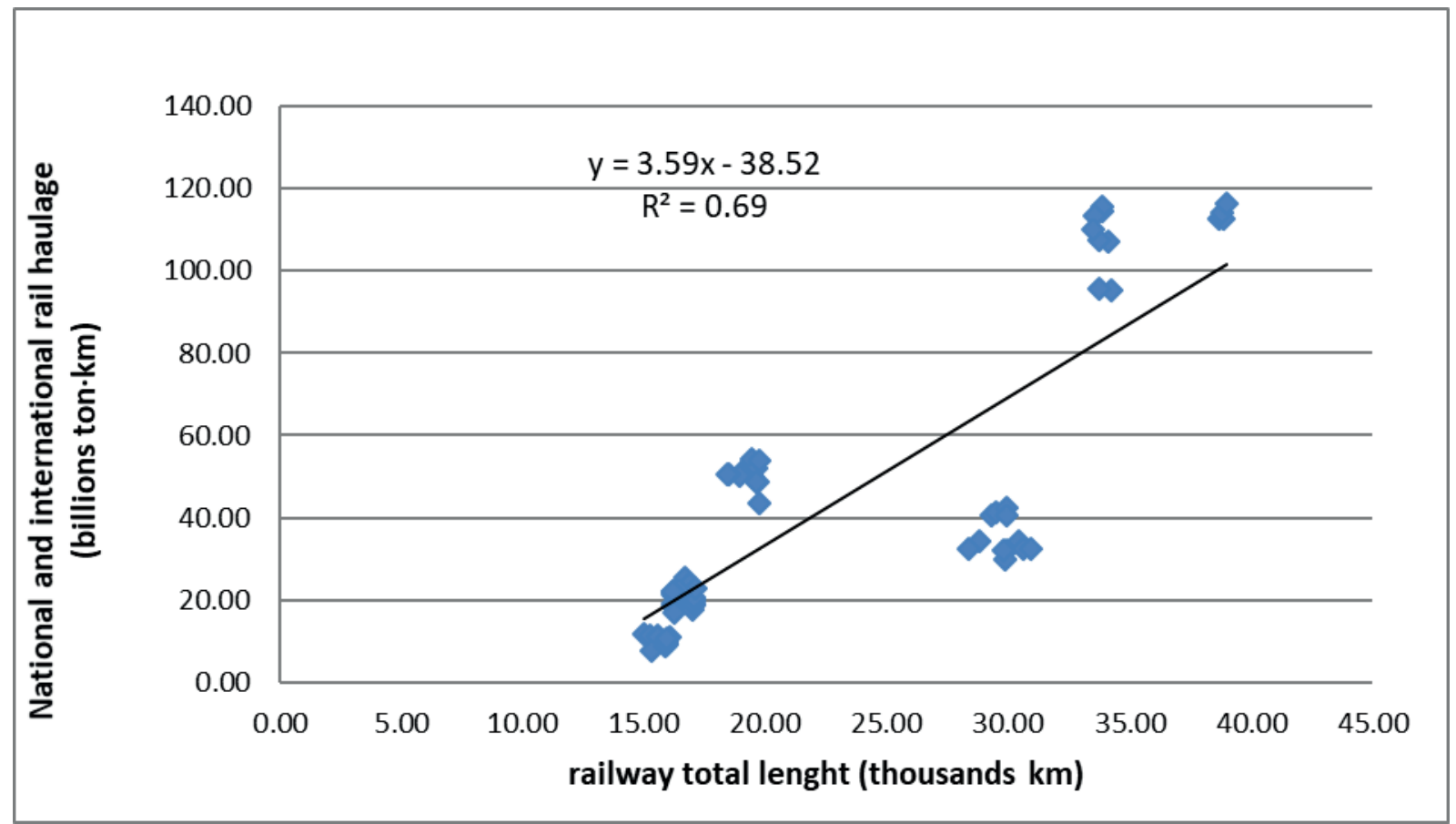

Figure 6 Relation between the rail freight and railway length for all analysed countries

the countries under analysis. This graph shows the positive correlation that seems to exist between these two variables.

\section{Conclusions}

In this paper, the socio-economic, infrastructural and road, as well the rail freight, traffic data have been analysed with reference to the following European countries: France, Germany, Italy, Poland, Spain and the United Kingdom. The analysis is focused on the trend of data registered in the period 2005-2016, when the negative reaction of GDP and land transport haulage can be clearly observed, following the economic crisis started in 2008. Indeed, this study confirms that the economic crisis and the consequent policy of austerity applied by many European governments, starting from year 2008, led, in many cases, to a drastic decrease in terms of freight traffic volumes, both by road and especially by rail. On the other hand, Poland has shown a continuous growth of both socio-economic and transport- related attributes in the period under consideration. In fact, Poland behaves very differently compared to other more mature economies and it emerges from other countries also by registering a total growth of motorway network length by $160 \%$, between 2005 and 2016. A comparison between the annual variation of analysed attributes leads to observation of some relations among them, to a different extent in the various countries included in the study sample. Indeed, correlations between different pairs of attributes have been evaluated, by taking into account the freight traffic volumes as a dependent variable. Road haulage seems to be strongly related to GDP trend, at least as far as Germany, Italy and Poland are concerned. Moreover, it has been observed that a positive variation in the oil price involved, on average, a shift for freight from road to rail transport, with a significant decrease of the $\mathrm{CO}_{2}$ emissions. Finally, Poland appears to be the best performing country in the period under study, for what concerns both economic parameters and the road and rail transport of goods.

\section{References}

[1] OTTEMOLLER, O., FRIEDRICH, H. Modelling change in supply-chain-structures and its effect on freight transport demand. Transportation research part E: Logistic and Transportation Review [online]. 2018, 121(C), p. 23-42. ISSN 1366-5545. Available from: https://doi.org/10.1016/j.tre.2017.08.009

[2] TRLAKOVIC, J., DESPOTOVIC, D, RISTIC, L. Impact of technology-intensive exports on GDP of Western Balkan Countries. Journal of Policy Modeling [online]. 2018, 40(5), p. 1038-1049. ISSN 0161-8938, eISSN 1873-8060. Available from: https://doi.org/10.1016/j.jpolmod.2018.01.006

[3] GAO, Y. ZHANGA, Y., LI, H., PENG, T., HAO, S. Study on the relationship between comprehensive transportation freight index and GDP in China. Procedia Engineering [online]. 2016, 137, p. 571-580. eISSN 1877-7058. Available from: https://doi.org/10.1016/j.proeng.2016.01.294 
[4] VARJAN, P., ROVNANIKOVA, D., GNAP, J. Examining changes in GDP on the demand for road freight transport. Procedia Engineering [online]. 2017, 192, p. 911-916. eISSN 1877-7058. Available from: https://doi.org/10.1016/j.proeng.2017.06.157

[5] ALISES, A., VASSALLO, J. Comparison of road freight transport trends in Europe. Coupling and decoupling factors from an Input-Output structural decomposition analysis. Trasportation Research part A: Policy and Practice [online]. 2015, 82, p. 141-157. ISSN 0965-8564, eISSN 1879-2375. Available from: https://doi.org/10.1016/j.tra.2015.09.013

[6] LUPI, M., MANTECCHINI, L., RUPI, F. Econometric models for the Italian railway transportation demand. Ingegneria Ferroviaria. 2004, 3(3), p. 237-24. ISSN 0020-0956. Available from: http://hdl.handle.net/11568/187961

[7] FERRARI, P. Some necessary conditions for the success of innovations in rail freight transport. Transportation Research Part A: Policy and Practice [online]. 2018, 118, p. 747-758. ISSN 0965-8564, eISSN 1879-2375. Available from: https://doi.org/10.1016/j.tra.2018.10.020

[8] MOSCHOVOU, T. Freight transport impacts from the economic crisis in Greece. Transport policy [online]. 2017, 57, p. 51-58. ISSN 0967-070X, eISSN 1879-310X. Available from: https://doi.org/10.1016/j.tranpol.2017.04.001

[9] ENGSTROM, R. The Roads' Role in the freight Transport System. Transportation Research Procedia [online]. 2016, 14, p. 1443-1452. ISSN 2352-1465. Available from: https://doi.org/10.1016/j.trpro.2016.05.217

[10] HOLGUIN-VERAS, J., LEA, J. A., SANCHEZ-DIAZ, I., BROWNE, M., WOJTOWICZ, J. State of the art and practice of urban freight management: Part I: Infrastructure, vehicle-related, and traffic operations. Transportation Research Part A: Policy and Practice [online]. 2018. ISSN 0965-8564, eISSN 1879-2375. Available from: https://doi.org/10.1016/j.tra.2018.10.037

[11] KELLNER, F., OTTO, A., BRABANDER, C., Bringing infrastructure into pricing in road freight transportation a measuring concept based on navigation service data. Transportation Research Procedia [online]. 2017, 25, p. 794805. ISSN 2352-1465. Available from: https://doi.org/10.1016/j.trpro.2017.05.458

[12] KHALED, A. A., MINGZHOU, J., CLARKE, D. B., HOQUE, M. A. Train design and routing optimization for evaluating criticality of freight railroad infrastructures. Transportation Research Part B: Methodological [online]. 2015, 71, p. 71-84. ISSN 0191-2615. Available from: https://doi.org/10.1016/j.trb.2014.10.002

[13] WIEGMANS, B., CHAMPAGNE-GELINAS, A., DUCHESNE, S., SLACK, B., WITTE, P. Rail and road freight transport network efficiency of Canada, member states of the EU, and the USA. Research in Transportation Business \& Management [online]. 2018, 28, p. 54-65. Available from: https://doi.org/10.1016/j.rtbm.2018.10.004

[14] GAVRIILIDIS, K., KAMBOUROUDIS, D. S., TSAKOU, K., TSOUKNIDIS, D. A. Volatility forecasting across tanker freight rates: the role of oil price shocks. Transportation Research Part E: Logistics and Transportation Review [online]. 2018, 118, p. 376-391. ISSN 1366-5545. Available from: https://doi.org/10.1016/j.tre.2018.08.012

[15] LI T., XUE, L., CHEN, Y., CHEN, F., MIAO, Y., SHAO, X., ZHANGE, CH. Insights from multifractality analysis of tanker freight market volatility with common external factor of crude oil price. Physica A: Statistical Mechanics and its Applications [online]. 2018, 505, p. 374-384. ISSN 0378-4371. Available from: https://doi.org/10.1016/j.physa.2018.02.107

[16] Statistical Pocketbook from 2005 to 2016 - European commission [online]. Available from: https://ec.europa.eu/transport/

[17] Keystat from 2005 to 2016 - ITF [online]. Available from: https://www.itf-oecd.org/key-transport-statistics

[18] Oil price data - U. S. Energy Information Administration [online]. Available from: https://www.eia.gov/

[19] KANG, W., PEREZ DE GRACIA, F., RATTI, R., The asymmetric response of gasoline price to oil price shocks and policy uncertainty. Energy Economics [online]. 2018, 77, p. 66-79. ISSN 0140-9883, eISSN 1873-6181. Available from: https://doi.org/10.1016/j.eneco.2018.09.007 